\title{
Brachybacterium zhongshanense sp. nov., a cellulose-decomposing bacterium from sediment along the Qijiang River, Zhongshan City, China
}

\author{
Correspondence \\ Guoping Sun \\ guopingsun@163.com
}

\author{
Guoxia Zhang, Guoqu Zeng, Xiaowei Cai, Suier Deng, Huidong Luo \\ and Guoping Sun
}

\begin{abstract}
Guangdong Institute of Microbiology, Guangdong Provincial Key Laboratory of Microbiology Culture Collection and Application, Guangzhou 510070, China
\end{abstract}

\begin{abstract}
A cellulose-decomposing bacterium, strain $\mathrm{JB}^{\top}$, was isolated from sediments along the Qijiang River, Zhongshan City, China. Results of morphological, biochemical and chemotaxonomic characterization and 16S rRNA gene sequence analysis revealed that strain $\mathrm{JB}^{\top}$ belonged to the genus Brachybacterium. Insertion sequence-PCR fingerprinting patterns, DNA base ratio analysis and DNA-DNA hybridization data showed that strain $\mathrm{JB}^{\top}$ differed from recognized species of the genus Brachybacterium. Based on polyphasic analysis, strain $\mathrm{JB}^{\top}$ represents a novel species of the genus Brachybacterium, for which the name Brachybacterium zhongshanense sp. nov. is proposed. The type strain is $\mathrm{JB}^{\top}\left(=\mathrm{LMG} 23926^{\top}=\right.$ CGMCC $\left.1.6508^{\top}=\mathrm{DSM} 18832^{\top}\right)$.
\end{abstract}

Cellulosic materials are among the Earth's most abundant, renewable resources and micro-organisms play an important role in their degradation and utilization in nature. More and more researchers are becoming interested in cellulose degradation because of the potential for converting large amounts of photosynthetically produced cellulosic materials into industrial substrates. Many cellulolytic bacteria from soils and sediments secrete cellulases and xylanases that associate into high molecular mass complexes (Gal et al., 1997; Veiga et al., 1983).

During the course of collecting environmental microorganisms from various sources, sediments from along the Qijiang River, Zhongshan City, China, were sampled and used to isolate micro-organisms that decompose the cellulosic compounds of municipal solid waste. A sucrose manufacturing plant is located near the river and the sediment is rich in cellulose. One of the cellulosedecomposing micro-organisms was characterized. The taxonomic position of the isolate was determined. On the basis of morphological, biochemical, chemotaxonomic and molecular taxonomic characteristics, it was concluded that the isolate represents a novel species of the genus Brachybacterium.

The sediment samples were shaken for $2 \mathrm{~h}$ on a rotary shaker at 250 r.p.m. to disperse them and then suspensions were serially diluted with $0.85 \%(\mathrm{w} / \mathrm{v}) \mathrm{NaCl}$ solution. Each dilution $(0.1 \mathrm{ml})$ was plated into Congo red agar medium, $\mathrm{pH}$ 7.0, modified from Hendrick et al. (1995) containing

Abbreviation: IS-PCR, insertion sequence-PCR.

The GenBank/EMBL/DDBJ accession number for the 16S rRNA gene sequence of strain $\mathrm{JB}^{\top}$ is $\mathrm{EF} 125186$. $\left(\mathrm{g} \mathrm{l}^{-1}\right): \mathrm{KH}_{2} \mathrm{PO}_{4}(0.5), \mathrm{MgSO}_{4} .7 \mathrm{H}_{2} \mathrm{O}(0.25)$, cellulose powder (1.88), Congo red (0.2), gelatin (2.0) and agar (16). After 7 days incubation at $30{ }^{\circ} \mathrm{C}$, isolated colonies showing distinct red circles were selected and purified further on Congo red plates. Pure cultures were stored in $15 \%(\mathrm{w} / \mathrm{v})$ glycerol at $-20{ }^{\circ} \mathrm{C}$ and used for further testing. A number of the isolates had nearly identical results in Biolog GP2 MicroPlate assays after incubation for 1 day; one of these was selected as the type strain.

The reference strains used were: Brachybacterium rhamnosum LMG $19848^{\mathrm{T}}$, Brachybacterium fresconis LMG $20336^{\mathrm{T}}$, Brachybacterium nesterenkovii LMG $19549^{\mathrm{T}} \quad(=\mathrm{DSM}$ $\left.9573^{\mathrm{T}}\right)$, Brachybacterium paraconglomeratum LMG $19861^{\mathrm{T}}$ and Brachybacterium sacelli LMG $20345^{\mathrm{T}}$, all obtained from the Laboratorium voor Microbiologie, Rijksuniversiteit Gent, Ledeganckstraat 35, B-9000, Gent, Belgium; and Brachybacterium muris DSM $15460^{\mathrm{T}}$, which was obtained from the DSMZ, Braunschweig, Germany.

Cellulose-degrading ability was measured by following the loss in dry weight of either rice straw stalk or its powder. Either $2 \mathrm{~g}$ rice straw stalk or $2 \mathrm{~g}$ powder was mixed into $100 \mathrm{ml}$ zymolytic medium, $\mathrm{pH}$ 7.2, containing $\left(\mathrm{g} \mathrm{l}^{-1}\right)$ : peptone, 0.5; yeast extract, $0.5 ;\left(\mathrm{NH}_{4}\right)_{2} \mathrm{SO}_{4}, 2.0 ; \mathrm{KH}_{2} \mathrm{PO}_{4}$, 4.0; $\mathrm{CaCl}_{2} \cdot 2 \mathrm{H}_{2} \mathrm{O}, 0.3$; and $\mathrm{MgSO}_{4} \cdot 7 \mathrm{H}_{2} \mathrm{O}, 0.3$. A $5 \%$ inoculum was added and cultures were incubated at $30{ }^{\circ} \mathrm{C}$ with shaking at 150 r.p.m. (three replicates). After 6 days, the residual rice straw stalk or powder was harvested by centrifugation and washed repeatedly. The cellulose content was determined colorimetrically with $\mathrm{K}_{2} \mathrm{Cr}_{2} \mathrm{O}_{7}$ as described by Halliwell (1974). The cellulose-decomposing ratio (\%) was calculated according to the following formula: cellulose decomposed $(\%)=[(A-B) / A] \times 100$, in 
which $A$ is the initial weight of straw stalk (or powder) $\times$ cellulose content and $B$ is straw stalk (or powder) remaining $\times$ cellulose content of residual straw stalk (or powder).

For morphological, physiological and biochemical analysis, strain $\mathrm{JB}^{\mathrm{T}}$ was grown aerobically on Luria-Bertani (LB) plates (Sambrook et al., 1989) overnight at $30^{\circ} \mathrm{C}$. Microaerophilic conditions were maintained in an oxygen range varying between 0.01 and $0.5 \mathrm{mg} \mathrm{l}^{-1}$ without aeration in flasks at $30{ }^{\circ} \mathrm{C}$ for $36 \mathrm{~h}$. Anaerobic growth $\left(80 \% \mathrm{~N}_{2}, 10 \% \mathrm{CO}_{2}, 10 \% \mathrm{H}_{2}\right)$ on $\mathrm{LB}$ plates at $30{ }^{\circ} \mathrm{C}$ for $36 \mathrm{~h}$ was analysed by using a Bug Box anaerobic workstation (Ruskim). The Hucker method (Murray et al., 1994) was used for Gram staining. Gram staining was observed by normal light microscopy and cell morphology was examined by transmission electron microscopy after negative staining with $4 \%$ phosphotungstic acid, $\mathrm{pH}$ 7.0. Oxidase activity was determined by using $1 \%$ $(\mathrm{w} / \mathrm{v})$ tetramethyl-p-phenylene-diamine as the substrate. Catalase activity was determined by the detection of bubble formation in $3 \%(\mathrm{w} / \mathrm{v})$ hydrogen peroxide solution after incubation in LB medium for 18-24 h (Smibert \& Krieg, 1994). Carbon source utilization was tested by using Biolog GP2 MicroPlates. Overnight cultures were used to inoculate the GP2 MicroPlates, according to the manufacturer's instructions, and they were incubated at $30{ }^{\circ} \mathrm{C}$ for $24 \mathrm{~h}$; the colour result in each well was recorded by the Biolog MicroStation. Some biochemical tests were performed by using the Microbial Biochemical Identification Tube System (GuangDong Huankai Microbial Sci \& Tech). Tolerance to different $\mathrm{NaCl}$ concentrations $(0-15 \%$, w/v) and $\mathrm{pH}$ values (4-14) was measured spectrophotometrically (Bachman U 640) at $\mathrm{OD}_{550}$ in LB medium after 18$24 \mathrm{~h}$ incubation at $30{ }^{\circ} \mathrm{C}$; results were scored as positive if the change in $\mathrm{OD}_{550}$ was greater than 0.300 (Heyrman et al., 2002).

For analysis of cellular fatty acids, strain $\mathrm{JB}^{\mathrm{T}}$ was incubated for $36 \mathrm{~h}$ in LB medium at $30{ }^{\circ} \mathrm{C}$. Sample preparation was performed by the method of Song et al. (2000); extracts and analysis of cellular fatty acid methyl esters were as described by $\mathrm{Xu}$ et al. (2005).

The 16S rRNA gene was amplified from genomic DNA of the isolate by using forward primer $27 \mathrm{f}$ ( $5^{\prime}$-AGAGTTTGATCCTGGCTCAG-3') and reverse primer 1492r (5'TACGGYTACCTTGTTACGACTT- $3^{\prime}$ ). PCR conditions were as described by Hurek et al. (1997). The purified PCR product was sequenced directly by using the sequencing primers $35 \mathrm{f}\left(5^{\prime}\right.$-CTKAAGAGTTTGATCMTGGCTCAGATTGAACG-3'), 342f (5'-CTCCTACGGGAGGCAG-3') and 930f (5'-GGTTAAAACTYAAAKGAATTGACGGGGA- $3^{\prime}$ ). Sequencing was carried out by Shanghai Invitrogen Biotechnology and the nearly fulllength 16S rRNA gene sequence was compiled using SEQMAN software (DNASTAR).The determined sequence and some related sequences selected from GenBank with the program BLAST were aligned by using the RDP program
(Maidak et al., 1999). Alignment gaps and ambiguous bases were excluded from similarity calculations. Tree topology was inferred by using the neighbour-joining method (Saitou \& Nei, 1987) and the phylogenetic tree was visualized and bootstrapped by using the TREECON software package (Van de Peer \& De Wachter, 1994). The topology of the phylogenetic tree was evaluated by performing bootstrap analysis with 100 replicates.

Insertion sequence (IS)-PCR fingerprinting patterns were analysed to evaluate genotypic differences between strains $\mathrm{JB}^{\mathrm{T}}$, DSM $15460^{\mathrm{T}}$ and DSM $9573^{\mathrm{T}}$. The primer and reaction mixtures were as described by Peng et al. (2006). PCR began with denaturation at $94{ }^{\circ} \mathrm{C}$ for 7 min followed by 30 cycles of denaturation at $94{ }^{\circ} \mathrm{C}$ for $1 \mathrm{~min}$, annealing at $68{ }^{\circ} \mathrm{C}$ for $1 \mathrm{~min}$ and extension at $68{ }^{\circ} \mathrm{C}$ for $2 \mathrm{~min}$. The final extension cycle was at $65{ }^{\circ} \mathrm{C}$ for $15 \mathrm{~min}$. PCR products were separated in $1.2 \%$ agarose gels in $1 \times$ TAE buffer $(40 \mathrm{mM}$ Tris/acetate and $1 \mathrm{mM}$ EDTA at $\mathrm{pH}$ 8.3).

Genomic DNA from strain $\mathrm{JB}^{\mathrm{T}}$ and reference strains was isolated and purified as described by Marmur (1961) and DNA base composition was determined spectrophotometrically (De Ley et al., 1970). DNA from Escherichia coli $\mathrm{K}-12$ was used as the standard for estimation of $\mathrm{G}+\mathrm{C}$ content. DNA-DNA relatedness was determined by using the initial renaturation rate method (De Ley et al., 1970) in $2 \times$ SSC as modified by Tan et al. (2001). Hybridization experiments were carried out under optimal and stringent temperatures calculated from the melting temperature $\left(T_{\mathrm{m}}\right)$ based on the $\mathrm{G}+\mathrm{C}$ content of each test strain (three replicates for each test).

Cells of strain $\mathrm{JB}^{\mathrm{T}}$ were Gram-positive and mainly short rods, $0.48-0.65 \mu \mathrm{m}$ wide and $0.57-0.92 \mu \mathrm{m}$ long; any coccoid cells were $1 \mu \mathrm{m}$ in diameter (Fig. 1). Colonies on LB plates at $30{ }^{\circ} \mathrm{C}$ for $24 \mathrm{~h}$ were cream-coloured, smooth, glistening and grew well in an anaerobic chamber on LB plates under microaerophilic conditions at $30{ }^{\circ} \mathrm{C}$ for $36 \mathrm{~h}$.

Strain $\mathrm{JB}^{\mathrm{T}}$ showed cellulose-decomposing ratios of rice straw stalk and straw powder of $3.64 \pm 1.29$ and $1.62 \pm 2.73 \%$, respectively, after 6 days incubation at $30{ }^{\circ} \mathrm{C}$.

Phenotypic properties of strain $\mathrm{JB}^{\mathrm{T}}$ were consistent with its classification in the genus Brachybacterium. The major phenotypic properties of the isolate and the type strains of closely related species of the genus Brachybacterium (i.e. those with 16S rRNA gene sequence similarity above $97 \%$ ) are listed in Table 1; other characters are given in the species description.

The fatty acid profile of strain $\mathrm{JB}^{\mathrm{T}}$ contained predominantly anteiso- $\mathrm{C}_{15: 0}(37.38 \%)$ and anteiso- $\mathrm{C}_{17: 0}$ $(28.17 \%)$, which is similar to profiles of other known species of the genus Brachybacterium (Collins et al., 1988; Gvozdyak et al., 1992; Takeuchi et al., 1995; Schubert et al., 1996; Heyrman et al., 2002; Buczolits et al., 2003). Additionally, considerable amounts of iso- $\mathrm{C}_{16: 0}$ 

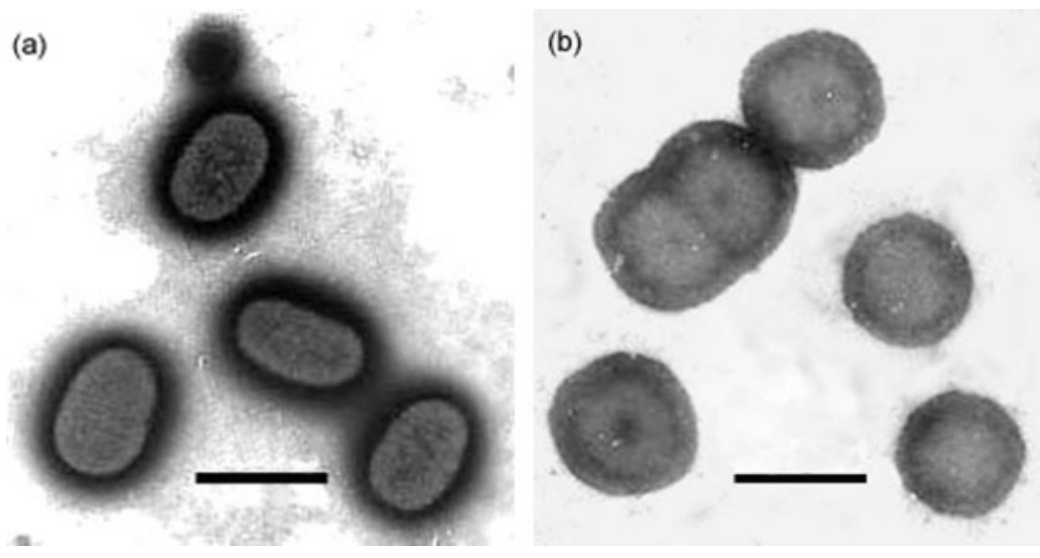

Fig. 1. Morphological features of cells of strain $\mathrm{JB}^{\top}$ observed by transmission electron microscopy. Cells in exponential (a; bar, $100 \mathrm{~nm}$ ) and stationary (b; bar, $62.5 \mathrm{~nm}$ ) phases are shown.
(13.13\%), iso- $\mathrm{C}_{15: 0}(9.22 \%), \mathrm{C}_{16: 0}(2.23 \%), \mathrm{C}_{20: 1} \omega 7 c$ $(2.20 \%)$, iso- $\mathrm{C}_{14: 0}(1.45 \%)$ and $\mathrm{C}_{14: 0}(1.42 \%)$ and minor amounts of an unknown lipid $(0.57 \%)$ were also present.
$16 \mathrm{~S}$ rRNA gene sequence analyses clearly demonstrated that strain $\mathrm{JB}^{\mathrm{T}}$ was affiliated to the genus Brachybacterium, as shown in Fig. 2. Data show that strain $\mathrm{JB}^{\mathrm{T}}$ formed a close

Table 1. Differential characteristics of strain $\mathrm{JB}^{\top}$ (Brachybacterium zhongshanense sp. nov.) and closely related species of the genus Brachybacterium

Strains: 1 , JB ${ }^{\mathrm{T}} ; 2$, B. muris DSM $15460^{\mathrm{T}} ; 3$, B. nesterenkovii DSM $9573^{\mathrm{T}} ; 4$, B. rhamnosum LMG $19848^{\mathrm{T}} ; 5$, B. sacelli LMG $20345^{\mathrm{T}}$; 6, B. fresconis $\mathrm{LMG}$ $20336^{\mathrm{T}} ;$ 7, B. paraconglomeratum LMG $19861^{\mathrm{T}}$. +, Positive; (+), weakly positive; -, negative; ND, not determined. All strains are catalase-positive and oxidase-negative. Except where indicated, all data are from this study and obtained under the same conditions as data from the other studies.

\begin{tabular}{|c|c|c|c|c|c|c|c|}
\hline Characteristic & 1 & 2 & 3 & 4 & 5 & 6 & 7 \\
\hline Cellulose-decomposing ability & + & - & - & - & - & - & - \\
\hline Nitrate reduction & + & - & + & + & + & + & + \\
\hline \multicolumn{8}{|l|}{ Growth at: } \\
\hline pH 5.0 & + & - & $(+)$ & + & + & + & - \\
\hline $30{ }^{\circ} \mathrm{C}$ & + & + & + & + & $(+)$ & $(+)$ & + \\
\hline $42{ }^{\circ} \mathrm{C}$ & $(+)$ & $(+)$ & - & - & - & - & + \\
\hline \multicolumn{8}{|l|}{ Growth in: } \\
\hline $5 \% \mathrm{NaCl}$ & + & + & $(+)$ & + & + & + & + \\
\hline $10 \% \mathrm{NaCl}$ & + & + & - & $(+)$ & + & + & $(+)$ \\
\hline Starch & - & + & - & + & - & - & + \\
\hline \multicolumn{8}{|l|}{ Acid production from: } \\
\hline D-Mannose & + & $(+)$ & - & + & $(+)$ & + & + \\
\hline Sucrose & + & + & + & + & - & - & + \\
\hline Maltose & + & + & $(+)$ & + & - & - & + \\
\hline D-Fructose & + & + & - & + & $+^{*}$ & + & + \\
\hline L-Rhamnose & + & + & - & - & $(+)$ & $(+)^{*}$ & - \\
\hline D-Sorbitol & + & - & - & $+\dagger$ & - & - & - \\
\hline DNA G $+C$ content $(\mathrm{mol} \%)$ & 71.2 & $\mathrm{ND}$ & $70.0 \ddagger$ & $71.5 \ddagger$ & $70.3 \ddagger$ & $70.4 \ddagger$ & $68.6 \ddagger$ \\
\hline
\end{tabular}

${ }^{\star}$ From Heyrman et al. (2002).

$\dagger$ From Takeuchi et al. (1995).

‡From Buczolits et al. (2003). 


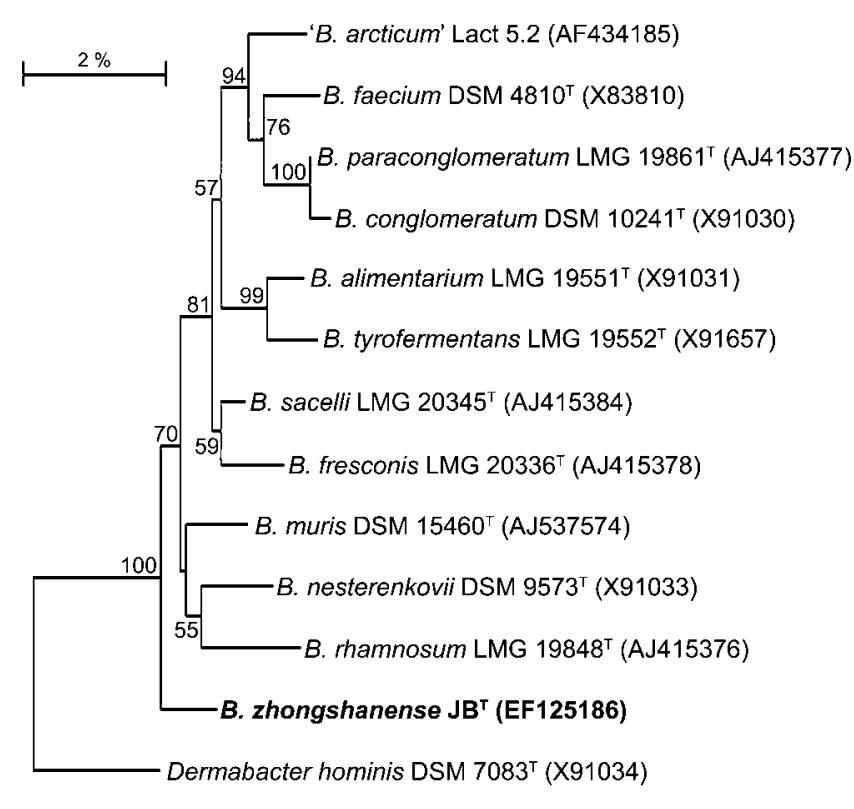

Fig. 2. Phylogenetic positions based on 16S rRNA gene sequences of strain $\mathrm{JB}^{\top}$ and the type strains of species of the genus Brachybacterium. Dermabacter hominis was included as an outgroup. Bootstrap values above $50 \%$ (expressed as percentages of 100 replications) are indicated at branch points. Bar, $2 \%$ sequence divergence.

cluster with B. muris (97.9\%), B. nesterenkovii (97.7\%), B. rhamnosum $(97.7 \%), \quad B$. sacelli $(97.6 \%)$, B. fresconis $(97.5 \%)$ and B. paraconglomeratum $(97.1 \%)$. Sequence similarities between strain $\mathrm{JB}^{\mathrm{T}}$ and other type strains of members of the genus Brachybacterium were in the narrow range $96.1-96.7 \%$; sequence similarity to another species of the family Dermabacteraceae, Dermabacter hominis DSM $7083^{\mathrm{T}}$, was $93.6 \%$ (bootstrap value of $100 \%$ ). However, the precise position of strain $\mathrm{JB}^{\mathrm{T}}$ within the genus is not very clear since the branching order among strain $\mathrm{JB}^{\mathrm{T}}, B$. muris and B. rhamnosum was not supported by a high bootstrap value $(<50 \%)$.

The 16S rRNA gene sequence of strain $\mathrm{JB}^{\mathrm{T}}$ showed similarities of 97.7 and $97.9 \%$ to those of B. nesterenkovii DSM $9573^{\mathrm{T}}$ and B. muris DSM $15460^{\mathrm{T}}$, respectively, so ISPCR fingerprinting patterns of three strains were made to distinguish them more precisely (Fig. 3). The three strains had 2-4 fragments between $250 \mathrm{bp}$ and $2000 \mathrm{bp}$ and the pattern for strain $\mathrm{JB}^{\mathrm{T}}$ differed distinctly from those of strains DSM $9573^{\mathrm{T}}$ and DSM $15460^{\mathrm{T}}$. This difference in genomic organization supports classification of strain $\mathrm{JB}^{\mathrm{T}}$ as a representative of a novel species of the genus Brachybacterium.

The $\mathrm{G}+\mathrm{C}$ content of the genomic DNA of strain $\mathrm{JB}^{\mathrm{T}}$ was $71.2 \pm 1.7 \mathrm{~mol} \%$, which is in the range expected for members of the genus Brachybacterium (68-72 mol\%).

It is necessary to perform DNA-DNA hybridization to judge whether a novel isolate belongs to a species when the

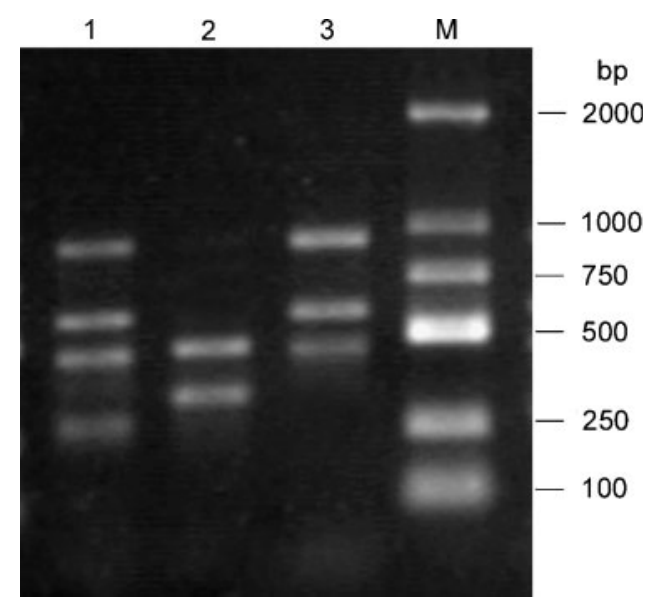

Fig. 3. IS-PCR fingerprinting patterns on $1.2 \%$ agarose gel electrophoresis of strain $\mathrm{JB}^{\top}$ (lane 1), B. nesterenkovii DSM $9573^{\top}$ (lane 2) and B. muris DSM $15460^{\top}$ (lane 3). Lane M, molecular mass marker (DME-50).

isolate and species representatives share more than $97 \%$ $16 \mathrm{~S}$ rRNA gene sequence similarity (Stackebrandt \& Goebel, 1994). Thus, six species (B. muris, B. sacelli, B. nesterenkovii, B. rhamnosum, $B$. fresconis and B. paraconglomeratum) were selected for DNA-DNA hybridization. Levels of DNA-DNA relatedness at optimal temperatures among these related species were 41-54\% (Table 2). All DNA-DNA relatedness values were below the threshold value that has been suggested as delineating a bacterial species (approx. 70\%) under optimal hybridization conditions $\left(T_{\mathrm{m}}\right.$ of $\left.25^{\circ} \mathrm{C}\right)$ (Grimont, 1999; Wayne et al., 1987). This confirmed the view that strain $\mathrm{JB}^{\mathrm{T}}$ represents a novel species of the genus Brachybacterium.

Table 2. DNA-DNA relatedness (\%) between strain $\mathrm{JB}^{\top}$ (Brachybacterium zhongshanense sp. nov.), B. muris, $B$. sacelli, $B$. nesterenkovii, $B$. rhamnosum, $B$. fresconis and $B$. paraconglomeratum

E. coli $\mathrm{K}-12$ was used as a negative control; DNA-DNA relatedness between strain $\mathrm{JB}^{\mathrm{T}}$ and $E$. coli $\mathrm{K}-12$ was $8 \pm 0.8 \%$.

\begin{tabular}{|lc|}
\hline Type strain & $\begin{array}{c}\text { DNA-DNA relatedness } \\
\text { with strain } \mathbf{~ J B}^{\mathrm{T}}(\%)\end{array}$ \\
\hline $\mathrm{JB}^{\mathrm{T}}$ & 100 \\
B. muris DSM $15460^{\mathrm{T}}$ & $54 \pm 3.2$ \\
B. sacelli LMG 20345 & $50 \pm 0.5$ \\
B. nesterenkovii DSM $9573^{\mathrm{T}}$ & $48 \pm 1.1$ \\
B. rhamnosum LMG $19848^{\mathrm{T}}$ & $46 \pm 2.9$ \\
B. fresconis LMG 20336 & $43 \pm 5.7$ \\
B. paraconglomeratum $\mathrm{LMG} 19861^{\mathrm{T}}$ & $41 \pm 3.6$ \\
\hline
\end{tabular}




\section{Description of Brachybacterium zhongshanense sp. nov.}

Brachybacterium zhongshanense (zhong.shan.en'se. N.L. neut. adj. zhongshanense pertaining to Zhongshan, a city in China, from where the type strain was isolated).

Cells vary in shape from coccoid forms (irregular) in the stationary phase to short rods in the exponential phase. Cells are non-motile, Gram-positive and do not form endospores. Colonies on LB plates are cream-coloured, smooth, glistening and grow well in an anaerobic chamber on LB plates. Temperature range for good growth is 25$40{ }^{\circ} \mathrm{C}$; no growth occurs at 4 or $45{ }^{\circ} \mathrm{C}$. Grows in $0-10 \%$ (w/v) $\mathrm{NaCl}$. Grows well at $\mathrm{pH} 5-8$ and weakly at $\mathrm{pH} 9-11$; no growth is observed at $\mathrm{pH} 12-14$. Catalase and urease are produced. Oxidase is not produced. Aesculin and gelatin are hydrolysed, but starch is not. Nitrate is reduced to nitrite. Indole is not produced. Positive for arginine dihydrolase and denitrification. Acid is produced from glucose. Utilizes the following carbon sources: $\alpha$-cyclodextrin, $\beta$-cyclodextrin, dextrin, glycogen, inulin, amygdalin, L-arabinose, arbutin, D-cellobiose, D-fructose, D-galactose, D-galacturonic acid, gentiobiose, $\alpha$-D-glucose, $\alpha$-D-lactose, lactulose, maltose, maltotriose, D-mannose, D-melezitose, D-melibiose, methyl $\alpha$-D-galactoside, methyl $\beta$-D-galactoside, methyl $\beta$-D-glucoside, palatinose, D-psicose, D-raffinose, stachyose, sucrose, D-tagatose, trehalose, turanose, xylitol, D-xylose, acetic acid, L-lactic acid, pyruvic acid methyl ester, pyruvic acid, glycerol, adenosine, inosine and thymidine. Predominant fatty acids are anteiso- $\mathrm{C}_{15: 0}$ and anteiso- $\mathrm{C}_{17: 0}$.

The type strain is $\mathrm{JB}^{\mathrm{T}} \quad\left(=\mathrm{LMG} \quad 23926^{\mathrm{T}}=\mathrm{CGMCC}\right.$ $1.6508^{\mathrm{T}}=$ DSM $\left.18832^{\mathrm{T}}\right)$, which was isolated from sediments along the Qijiang River, Zhongshan City, China. The DNA G + C content of strain $\mathrm{JB}^{\mathrm{T}}$ is $71.2 \mathrm{~mol} \%$.

\section{Acknowledgements}

The authors acknowledge the financial support of the funds of Chinese National Programs for High Technology Research and Development (2006106Z3063) and Guangdong Provincial Natural Science Fund (no. 015017).

\section{References}

Buczolits, S., Schumann, P., Weidler, G., Radax, C. \& Busse, H.-J. (2003). Brachybacterium muris sp. nov., isolated from the liver of a laboratory mouse strain. Int J Syst Evol Microbiol 53, 1955-1960.

Collins, M. D., Brown, J. \& Jones, D. (1988). Brachybacterium faecium gen. nov., sp. nov., a coryneform bacterium from poultry deep litter. Int J Syst Bacteriol 38, 45-48.

De Ley, J., Cattoir, H. \& Reynaerts, A. (1970). The quantitative measurement of DNA hybridization from renaturation rates. Eur $J$ Biochem 12, 133-142.

Gal, L., Pages, S., Gaudin, C., Belaich, A., Reverbel-Leroy, C., Tardif, C. \& Belaich, J. P. (1997). Characterization of the cellulolytic complex (cellulosome) produced by Clostridium cellulolyticum. Appl Environ Microbiol 63, 903-909.
Grimont, P. A. D. (1999). Taxonomy and classification of bacteria. In Manual of Clinical Microbiology, 7th edn, pp. 249-259. Edited by P. R. Murray, E. J. Baron, M. A. Pfaller, F. C. Tenover \& R. H. Yolken. Washington, DC: American Society for Microbiology.

Gvozdyak, O. R., Nogina, T. M. \& Schumann, P. (1992). Taxonomic study of the genus Brachybacterium: Brachybacterium nesterenkovii sp. nov. Int J Syst Bacteriol 42, 74-78.

Halliwell, G. (1974). Cellulose. In Methods of Enzymatic Analysis, pp. 1132-1142. Edited by H. U. Bergmeyer. New York: Academic Press Hendrick, C. W., Dolye, J. D. \& Hugley, B. (1995). A new solid medium for enumerating cellulose utilizing bacteria in soil. Appl Environ Microbiol 61, 2016-2019.

Heyrman, J., Balcaen, A., De Vos, P., Schumann, P. \& Swings, J. (2002). Brachybacterium fresconis sp. nov. and Brachybacterium sacelli sp. nov., isolated from deteriorated parts of a medieval wall painting of the chapel of Castle Herberstein (Austria). Int J Syst Evol Microbiol 52, 1641-1646.

Hurek, T., Egener, T. \& Reinhold-Hurek, B. (1997). Divergence in nitrogenases of Azoarcus spp., Proteobacteria of the $\beta$ subclass. J Bacteriol 179, 4172-4178.

Maidak, B. L., Cole, J. R., Parker, C. T., Jr, Garrity, G. M., Larsen, N., Li, B., Lilburn, T. G., McCaughey, M. J., Olsen, G. J. \& other authors (1999). A new version of the RDP (Ribosomal Database Project). Nucleic Acids Res 27, 171-173.

Marmur, J. (1961). A procedure for the isolation of deoxyribonucleic acid from microorganisms. J Mol Biol 3, 208-218.

Murray, R. G. E., Doetsch, R. N. \& Robinow, C. F. (1994). Determinative and cytological light microscopy. In Methods for General and Molecular Bacteriology, pp. 31-33. Edited by P. Gerhardt, R. G. E. Murray, W. A. Wood and N. R. Krieg. Washington, DC: American Society for Microbiology.

Peng, G. X., Wang, H. R., Zhang, G. X., Hou, W., Wang, E. T. \& Tan, Z. Y. (2006). Azospirillum melinis sp. nov., a group of diazotrophs isolated from tropical molasses grass. Int J Syst Evol Microbiol 56, $1263-1271$.

Saitou, N. \& Nei, M. (1987). The neighbor-joining method: a new method for reconstructing phylogenetic trees. Mol Biol Evol 4, 406-425.

Sambrook, J., Fritsch, E. F. \& Maniatis, T. (1989). Molecular Cloning: a Laboratory Manual, 2nd edn. Cold Spring Harbor, NY: Cold Spring Harbor Laboratory.

Schubert, K., Ludwig, W., Springer, N., Kroppenstedt, R. M., Accolas, J. \& Fiedler, F. (1996). Two coryneform bacteria isolated from the surface of French gruyere and Beaufort cheeses are new species of the genus Brachybacterium alimentarium sp. nov. and Brachybacterium tyrofermentans sp. nov. Int J Syst Bacteriol 46, 81-87.

Smibert, R. \& Krieg, N. R. (1994). Phenotypic characterization. In Methods for General and Molecular Bacteriology, pp. 607-654. Edited by P. Gerhardt, R. G. E. Murray, W. A. Wood \& N. R. Krieg. Washington, DC: American Society for Microbiology.

Song, Y.-J., Yang, R.-F., Guo, Z.-B., Zhang, M.-L., Wang, X.-H. \& Zhou, F. (2000). Distinctness of spore and vegetative cellular fatty acid profiles of some aerobic endospore-forming bacilli. J Microbiol Methods 39, 225-241.

Stackebrandt, E. \& Goebel, B. M. (1994). Taxonomic note: a place for DNA-DNA reassociation and 16S rRNA sequence analysis in the present species definition in bacteriology. Int $J$ Syst Bacteriol 44, 846-849.

Takeuchi, M., Fang, C. X. \& Yokota, A. (1995). Taxonomic study of the genus Brachybacterium: proposal of Brachybacterium conglomeratum sp. nov., nom. rev., Brachybacterium paraconglomeratum sp. nov., and Brachybacterium rhamnosum sp. nov. Int J Syst Bacteriol 45, $160-168$. 
Tan, Z. Y., Kan, F. L., Peng, G. X., Wang, E. T., Reinhold-Hurek, B. \& Chen, W. X. (2001). Rhizobium yanglingense sp. nov., isolated from arid and semi-arid regions in China. Int J Syst Evol Microbiol 51, 909-914.

Van de Peer, Y. \& De Wachter, R. (1994). TREECON for windows: a software package for the construction and drawing of evolutionary trees for the Microsoft windows environment. Comput Appl Biosci 10, 569-570.

Veiga, M., Esparis, A. \& Fabregas, J. (1983). Isolation of cellulolytic actinomycetes from marine sediments. Appl Environ Microbiol 46, 286-287.
Wayne, L. G., Brenner, D. J., Colwell, R. R., Grimont, P. A. D., Kandler, P., Krichevsky, M. I., Moore, L. H., Moore, W. E. C., Murray, R. G. E. \& other authors (1987). International Committee on Systematic Bacteriology. Report of the ad hoc committee on reconciliation of approaches to bacterial systematics. Int J Syst Bacteriol 37, 463-464.

Xu, M., Guo, J., Cen, Y., Zhong, X., Cao, W. \& Sun, G. (2005). Shewanella decolorationis sp. nov., a dye-decolorizing bacterium isolated from activated sludge of a waste-water treatment plant. Int $J$ Syst Evol Microbiol 55, 363-368. 